\title{
Contagious suicide in prisons and police cells
}

\author{
Brian Cox, Keren Skegg
}

\begin{abstract}
Study objective-The aim was to determine whether clustering of suicide occurred in prisoners and detainees in police cells and to describe the characteristics of any clusters identified.

Design-Mortality from suicide was examined for evidence of clusters.

Setting-Prisons (1971-1988) and police cells (1980-September 1991) in New Zealand.

Subjects -82 male suicides.

Main results-There were 38 male suicides in prisons and 44 in police cells over the time periods. Due to the increasing trend in prison suicides, the 1971-1982 and 1983-1988 time periods were examined for evidence of clusters separately. For suicides in police cells the time periods studied were 1980-1982, 1983-1988, and 1989-1991. The event of suicide was treated as a Poisson process with all suicides in a time period used to calculate the mean. Four suicide clusters occurred between 1985 and 1988 in prisons. These did not explain the increased suicide rate over this period. Three clusters of suicide in police cells occurred between 1980 and 1991, which had different characteristics from suicide in prisons in that these three clusters were of longer duration.

Conclusions-The different characteristics of prison and police cell clusters of suicide indicated separate transmission of the contagious component of suicide between these groups. Distinct strategies to reduce clusters of male suicide in custody are required for prisoners and those held in police cells.
\end{abstract}

f Epidemiol Community Health 1993; 47: 69-72

University of Otago Medical School, Box 913, Dunedin, New Zealand:

Hugh Adam Cancer Epidemiology Unit, Department of

Preventive and Social

Medicine

M Cox

Department of

Psychological

Medicine

K Skegg

Correspondence to: Dr Cox

Accepted for publication July 1992
Clusters of suicides occur occasionally in the general population ${ }^{1}$ and recommendations for their prevention and containment have been made. ${ }^{2}$ Clusters can occur in space, that is, confined to a defined locality or institution such as a school or hospital, ${ }^{13}$ or in time, as frequent events within a defined time period. ${ }^{4}$ Clusters of suicide may also occur in maximum security prisons $^{5}$ or among prisoners in police lock ups. ${ }^{6}$

In New Zealand, a recent increase in prison suicide rates from 27 to 178 per 100000 manyears between the 1973-1982 and 1983-1987 time periods appears to have been due partly to decreased access to adequate psychiatric care for inmates in the Auckland area. ${ }^{7}$ The suicide rate increased from 37 to 549 per 100000 man-years between the two time periods in Auckland, where
New Zealand's only maximum security prison is sited. A retrospective assessment of the circumstances and likely mental state of prisoners who committed suicide at the maximum security prison between 1983 and 1988 was available. ${ }^{8}$ Eight of the 13 prisoners who committed suicide in the maximum security prison from 1983 to 1988 were considered to have been so mentally disturbed that in other circumstances they would probably have been committed. A further four were considered to have shown signs of being emotionally disturbed prior to their deaths although they were probably not committable. The frequency of suicide in New Zealand prisoners was examined for evidence of clustering and an assessment of the effect of clustering on the increased prison suicide rate was made. The frequency of suicides in police station cells from 1980 to 30 September 1991 was also assessed for evidence of clusters.

\section{Methods}

The date, age, ethnicity, and place of internment of almost all of the 38 suicides among male prisoners in New Zealand from 1971 to 1988 , and the 44 male suicides in police cells from 1980 to September 1991 was provided by the Department of Justice. A ministerial inquiry into the background and circumstances of suicides from 1983 to 1987 in New Zealand's only maximum security prison provided an assessment of the mental state of 13 of the 24 prisoners who committed suicide in this period. ${ }^{8}$ Because of the increasing trend in prison suicide, the 1971-82 and 1983-88 time periods were examined for evidence of clusters separately. For suicides in police cells, the 1980 1982, 1983-1988, and 1989-1991 time periods were examined separately. The event of suicide was treated as a Poisson process with all suicides in a time period used to calculate the mean. If the probability of the number of suicides observed within a short time period was less than $5 \%$ a cluster was considered likely. When the chance of an observed group of suicides was close to this value, additional information when available (such as geographical proximity) was considered in deciding the presence of a cluster. This resulted in the addition of one cluster in police cells. The sequences of suicides were examined separately in monthly, two-monthly, three-monthly, and fourmonthly intervals to assess the size of clusters. The size of the prison population in New Zealand was relatively constant over each time period studied ${ }^{9}$ but the annual number of men held in police cells was not known.

Differences between age groups in the proportion of all suicides that were considered contagious suicides were assessed using Fisher's 
Table I The number of male suicides by month and year in New Zealand prisons

\begin{tabular}{|c|c|c|c|c|c|c|c|c|c|c|c|c|c|c|c|c|c|c|c|}
\hline \multirow[b]{2}{*}{ Month } & \multicolumn{18}{|l|}{ Year } & \multirow[b]{2}{*}{ Total } \\
\hline & 1971 & 1972 & 1973 & 1974 & 1975 & 1976 & 1977 & 1978 & 1979 & 1980 & 1981 & 1982 & 1983 & 1984 & 1985 & 1986 & 1987 & 1988 & \\
\hline January & - & - & - & - & - & - & 1 & - & - & - & - & - & - & 1 & - & - & - & - & 2 \\
\hline $\begin{array}{l}\text { February } \\
\text { March }\end{array}$ & - & $\overline{-}$ & - & $\overline{-}$ & $\overline{-}$ & $=$ & - & $\overline{-}$ & $\bar{z}$ & $\overline{-}$ & $\overline{-}$ & $\overline{-}$ & $\overline{1}$ & $\overline{-}$ & 1 & $\begin{array}{l}- \\
-\end{array}$ & 1 & - & $\begin{array}{l}2 \\
4\end{array}$ \\
\hline $\begin{array}{l}\text { March } \\
\text { April }\end{array}$ & $\overline{-}$ & - & $\overline{-}$ & - & - & - & - & - & - & 1 & - & - & - & 1 & 1 & - & - & 1 & $\begin{array}{l}4 \\
4\end{array}$ \\
\hline May & 1 & - & - & - & - & - & - & - & - & - & - & - & - & - & - & - & - & 1 & 2 \\
\hline June & - & - & - & 1 & - & - & 1 & - & - & - & - & - & 1 & - & 3 & - & - & 1 & 7 \\
\hline July & - & - & - & - & - & - & - & - & - & - & - & - & - & 1 & - & 1 & - & - & 2 \\
\hline August & - & - & - & - & - & 1 & - & - & - & $\bar{s}$ & - & - & - & 1 & 1 & - & - & - & 3 \\
\hline September & & - & - & - & - & - & - & - & - & 1 & - & - & - & - & - & - & - & - & 1 \\
\hline October & & - & - & - & - & - & - & - & - & - & - & - & - & 1 & 1 & $\overline{2}$ & - & $\bar{j}$ & 2 \\
\hline $\begin{array}{l}\text { November } \\
\text { December }\end{array}$ & $=$ & $=$ & $\begin{array}{c}- \\
-\end{array}$ & $\begin{array}{c}- \\
-\end{array}$ & $\overline{-}$ & $\begin{array}{l}- \\
-\end{array}$ & $\overline{-}$ & $\overline{-}$ & $\overline{-}$ & $\overline{-}$ & $\overline{-}$ & $\overline{1}$ & - & - & $\overline{1}$ & 2 & $\overline{1}$ & $\begin{array}{l}1 \\
2\end{array}$ & $\begin{array}{l}3 \\
6\end{array}$ \\
\hline
\end{tabular}

exact test. ${ }^{10}$ The frequency with which at least one suicide in prisons was associated with the presence or absence of any suicide in police cells, and vice versa, was used to measure the association between the two sequences of suicides from 1980 to 1988 . The resulting contingency table assessed whether three-month intervals with greater than average numbers of suicides in prisons were associated with greater than average numbers of suicides in police cells, or vice versa.

The time intervals between initial and postinitial suicides in each cluster were combined to assess the time course of an average epidemic of suicide in prison and police cells. Since the distribution of the time between initial and postinitial suicide was expected to be skewed, lognormal transformations were undertaken before the mean durations of epidemics in prisons and police cells were compared.

\section{Results}

The numbers of male suicides in New Zealand prisons from 1971 to 1988 for each month of the year are presented in table I.

From 1971 to 1982 prison suicide occurred at an average of 0.056 per month. In no month did more than one suicide occur and no clusters were observed in this time period. From 1983 to 1988 the chance of two suicides in one month was 0.06 , for three suicides occurring in one month 0.008 , for three suicides occurring within two months 0.042 , and for four suicides occurring within three months 0.029 . Four time periods of increased suicide frequency were identified, occurring in June 1985, November to December 1986, February to March 1987, and November to December 1988. For the suicides occurring in November to December 1988, 46 days passed between the first suicide and the other two suicides, which occurred within three days. Therefore, as well as the other three episodes of increased suicide frequency, only the two suicides in December 1988 were considered to be a cluster.

Table II The number of male suicides by month and year in police cells (excludes two suicides with unknown dates)

\begin{tabular}{lllllllllllllllllll}
\hline & \multicolumn{1}{l}{ Year } \\
\cline { 2 - 8 } Month & 1980 & 1981 & 1982 & 1983 & 1984 & 1985 & 1986 & 1987 & 1988 & 1989 & 1990 & $1991^{a}$ & Total \\
\hline January & - & - & - & - & - & - & 1 & - & - & - & 2 & 1 & 4 \\
February & - & - & - & - & - & - & - & - & - & - & 2 & 2 & 4 \\
March & - & - & - & - & - & - & - & 1 & - & - & - & - & 1 \\
April & 1 & - & - & - & - & - & - & - & - & - & - & - & 1 \\
May & 2 & 1 & 1 & - & 1 & 1 & - & - & - & - & - & 1 & 7 \\
June & 1 & 1 & - & - & - & 1 & - & - & - & - & 2 & - & 5 \\
July & 1 & - & - & - & - & - & 1 & - & - & - & - & 1 & 3 \\
August & - & 1 & - & - & - & - & 1 & - & - & - & - & - & 2 \\
September & 1 & - & - & - & - & - & - & - & 1 & - & 1 & - & 3 \\
October & - & - & - & 2 & - & - & - & - & - & - & 1 & & 3 \\
November & - & - & - & - & - & - & - & - & - & 1 & - & & 1 \\
December & - & - & 1 & - & - & - & 1 & 1 & 2 & 2 & 1 & & 8
\end{tabular}

${ }^{a}$ Only up to 30 September included
Three of the eight post-initial suicides occurred within a week, and four occurred from 8 to 23 days of the initial suicide. The average time between suicides in these clusters was 11 days. For those where age was known, two of seven post-initial suicides and 13 of the 29 other suicides were aged less than 25 .

Of the 12 suicides in the clusters, seven occurred in the maximum security prison. Only one maximum security prisoner was the first suicide of any of the four clusters. Of the 15 suicides at the maximum security prison between 1971 and 1988, seven contributed to the four clusters of suicide in the prison service.

An assessment of the mental state of all 13 suicides in the maximum security prison during the 1983-87 time period found eight who would have been committed if admission to a secure psychiatric treatment centre had been more readily available. ${ }^{8}$ Six of the 13 suicides were postinitial suicides in the three clusters identified during this period. Of these six prisoners, three would have been committed in other circumstances and the other three inmates were probably not committable prior to their deaths, although they did show evidence of emotional disturbance. Those prisoners who took their lives at the maximum security prison who would in other circumstances have been committed did not appear more likely to be post-initial suicides than prisoners who would not have been committed in the three clusters identified in the 1983-87 time period.

Excluding the post-initial suicides in each cluster to remove the effect of the clusters reduced the prison suicide rate from 178 to 126 per 100000 man-years for the 1983-87 time period. After removing the effect of the clusters, the prison suicide rate in the Auckland area decreased from 549 to 336 per 100000 man-years for the same time period. These rates were still considerably higher than both the suicide rates for the unconfined population (21.8 per 100000 man-years) or the prison suicide rate for prisoners outside the Auckland area (61.1 per 100000 man-years). ${ }^{7}$

The numbers of male suicides in police cells from 1980 to September 30 1991, for each month of the year, are presented in table II.

Three episodes of increased suicide frequency in police cells were identified: April to July 1980, November 1989 to February 1990, and December 1990 to February 1991. The most recent episode consisted of four suicides, not quite sufficient to be considered a cluster in time, but three occurred in two towns within $100 \mathrm{~km}$ of each other and these three suicides, in January and February 1991, were considered to be a cluster. The three clusters involved 12 post-initial suicides. In no 
cluster did a post-initial event occur within a week of the first suicide and only one suicide occurred between 7 and 13 days of the initial suicide. Five occurred between 14 and 41 days, four between 42 and 83 days, and two more than 84 days after the initial suicide. The average time for a post-initial suicide after the initial suicide was 56 dayssignificantly longer than the 11 days for suicide clusters in prisons. In the three clusters, nine of the 12 post-initial suicides and 14 of the 28 other suicides for whom age was known were less than 25 years of age. In this small series of prison and police cell suicides, younger age was not significantly associated with post-initial suicide.

From 1980 to 1988, 33 suicides in prison and 26 suicides in police cells occurred, both sequences averaging less than one suicide every three months. Neither the clusters of suicide nor the overall sequence of suicides in prisons and police cells appeared to be associated with one another (table III)

Though the odds of the concurrence of at least one suicide within prisons and police cells in any three month interval were twice that of the discordance in suicide events, the association was not statistically significant.

\section{Discussion}

Four suicide clusters occurring between 1985 and 1988 contributed to, but did not explain, the recent increased suicide rate among male prisoners in New Zealand. After adjusting for these clusters, prison suicide rates in the Auckland region remained high in the 1983-1987 period compared to the 1973-1982 period. Of those maximum security prisoners whose suicide contributed to the clusters in this small series, inmates likely to have been committable to psychiatric care did not appear more likely to contribute to post-initial suicides.

Within each cluster in prisoners, the increased risk of subsequent suicide appeared to be confined to the four week period after the initial suicide and was less likely over time. Heightened awareness of this risk period by prison administration and psychiatric services may allow action to be taken to prevent clusters of prison suicide occurring.

The three clusters of suicide in police cells from 1980 to 1991 appeared to have different characteristics from suicide clusters in prisons. The epidemics were of longer duration than, and did not coincide with, clusters of suicide in prison, suggesting different transmission characteristics of the contagious component of suicide in these populations. A post-initial suicide cannot occur in a police cell until a susceptible individual has been detained and thus some time may elapse. Also, suicidal ideas may not occur until detainment.

Table III The number of three month intervals from 1980 to 1988 in which no or at least one suicide occurred in prisons or police cells

\begin{tabular}{llll}
\hline & Police cells & \\
\cline { 2 - 3 } Prisons & $\begin{array}{l}\text { Intervals with } \\
\text { no suicides }\end{array}$ & $\begin{array}{l}\text { Intervals with } \\
\text { at least one suicide }\end{array}$ & Total \\
\hline $\begin{array}{l}\text { Intervals with } \\
\text { no suicides }\end{array}$ & 11 & 6 & 17 \\
$\begin{array}{l}\text { Intervals with at } \\
\text { least one suicide }\end{array}$ & 9 & 10 & 19 \\
Total & 20 & 16 & 36 \\
\hline Odds ratio $=2 \cdot 0(95 \%$ CI $0 \cdot 4-9 \cdot 8)$ & &
\end{tabular}

The long duration of suicide clusters in police cells does not suggest that the clusters identified could be explained by short term fluctuations in the number of detainees over the time period studied. As in Australia, ${ }^{11}$ no strong temporal association between suicides in prisons and police cells was found.

Suicide appears to have a contagious component which is poorly understood; however, the spread of ideas and rumours within a population can be modelled by epidemic theory. ${ }^{12}$ The contagious nature of suicide may become more evident when the underlying suicide rate increases. This is not uncommon with other forms of contagion. Other concepts of epidemic theory may also be directly relevant to the contagious component of suicide. The threshold theorem of epidemics indicates that simple epidemics occur when the number of susceptibles exceeds the ratio of the rate of removal to the rate of infection of susceptibles. ${ }^{13}$ Three strategies to prevent contagious suicide in prison seem possible. First, the number of susceptibles in prisons could be reduced through access to secure psychiatric care for prisoners with psychiatric illness. ${ }^{7}$ Second, if susceptibles are identifiable after a prison suicide, their removal or treatment could reduce the chance of an epidemic. Unfortunately, little is known about the victims of the post-initial suicides of clusters ${ }^{14}$ except that in the USA suicide clusters were found to occur mainly in the young. ${ }^{1}$ In these small epidemics of suicide in prison, only those with suspected psychiatric illness or signs of recent emotional disturbance were identifiable as susceptible. In $1987,5^{\circ}$ o of male prisoners in New Zealand were considered by the prison service to require psychiatric care and $38 \%$ had experienced at least one significant life event in the previous two years. ${ }^{15}$ Knowledge about who is most susceptible to cluster suicide needs to improve before the method of removing susceptibles can be used effectively. Third, the transmission rate of the knowledge that a suicide has occurred could be decreased within the prison service. In a relatively small country such as New Zealand, suicides in prison are likely to be reported in the press or on television: thus the media act as a vector. Reporting of suicide in a sensational way may increase the chance of clusters occurring. ${ }^{216}$ However, regardless of media coverage, a suicide may become known quickly throughout the prison population.

Preventing suicide in police cells may be more difficult than in prisons for several reasons. First, custodians of these men have a relatively short time in which to make an assessment of the mental state of their detainees. Second, detainees are probably more likely to be in a distressed state or to have recently consumed drugs or alcohol. Third, fewer resources for observing those in custody are likely to be available. Fourth, some localities are not as likely as others to have acute psychiatric services available to them.

Though the information will not always be generalisable to the population at large, characteristics of the contagious component of suicide or attempted suicide need to be monitored through the investigation of outbreaks, particularly in defined or monitored populations such as those residing in hospitals, schools, or prisons. 
Greater understanding of the contagious nature of suicide may help the custodians of people in institutions to prevent suicide.

We thank the New Zealand Departments of Justice, Police, Statistics, and Health (Statistical Services) for providing data not included in published reports.

1 Centers for Disease Control. Cluster of suicides and suicide attempts-New Jersey. MMWR 1988; 37: 213-6.

2 Centers for Disease Control. CDC recommendations for a community plan for the prevention and containment of suicide clusters. MMWR 1988; 37 (suppl S-6): 1-12.

3 Crawford JP, Willis JH. Double suicide in psychiatric hospital patients. Br F Psychiatry 1966; 112: 1231-5.

4 Robbins D, Conroy RC. A cluster of adolescent suicide attempts: is suicide contagious? 7 Adolesc Health Care 1983 3: 253-5.

5 Hurley W. Suicides by prisoners. Med $\mathcal{F}$ Aust 1989; 151: $188-90$.

$6 \mathrm{Niemi} \mathrm{T}$. The time-space distances of suicides committed in the lock-up in Finland in 1963-1967. Psychiatr Fennica the lock-up in
7 Skegg K, Cox B. Impact of psychiatric services on prison suicide. Lancet 1991; 338: 1436-8.

8 Report of the Committee of Inquiry into procedures used in certain psychiatric hospitals in relation to admission, discharge or release on leave of certain classes of patients. discharge or release on leave of certain

Wellington: Government Printer, 1988 .
9 Report of the Department of Justice. Wellington Report of the Department of
Government Printer, 1974 et seq.

10 Fisher RA. The design of experiments. Edinburgh: Oliver and Boyd, 1935

11 Reser JP. Australian aboriginal suicide deaths in custody cultural context and cluster evidence. Aust Psychol 1989; 24: 325-42.

12 Daley DJ, Kendall DG. Epidemics and rumours. Nature 1964; 204: 1118 .

13 Bailey NTJ. The mathematical theory of infectious diseases. 2nd ed. London: Griffin, 1975: 82-5.

14 Shaffer D, Garland A, Gould M, Fisher P, Trautman P. Preventing teenage suicide: a critical review. $\mathcal{F}$ Am Acad Child Adolesc Psychiatry 1988; 27: 675-87.

15 Braybrook B, O'Neill R. A census of prison inmates. Policy and Research Division, Wellington: Department of Justice, 1988.

16 Phillips DP, Carstensen LL. Clustering of teenage suicides after television news stories about suicide. $N$ Engl $f \mathrm{Med}$ 1986; 315: 685-9. 